\title{
MEDIA DESIGNING OF SOCIAL PROBLEMS IN MODERN UKRAINE
}

\author{
Klymanska L. D., \\ Sc.D (Politology), Full Professor, \\ Department of Sociology and Social Work \\ "Lviv Polytechnic" National University \\ Baibakova I. M., \\ Ph.D, Associate Professor, \\ Department of Foreign Languages \\ "Lviv Polytechnic" National University
}

The issues concerning the media designing practices of social problems are considered in the article, namely, the practice of setting the agenda, the practice of priming and the practice of framing. Each of the above-mentioned practices of designing a social problem is considered within the framework of contemporary Ukrainian political realities regarding the so-called linguistic problem. Practices of influence on the process of challenging complex social circumstances make it possible to fix not only the result of influences, but also to understand the mechanism of the influence itself involved in this process.

У статті розглядаються питання, що стосуються методів проектування засобами масової інформації соціальних проблем, а саме практика встановлення порядку денного, праймінгу та практика фреймінгу. Кожна з наведених практик проектування соціальної проблеми розглядається в межах сучасних українських політичних реалій щодо так званої мовної проблеми. Практика впливу на процес складних соціальних обставин дає можливість не лише зафіксувати результат впливу, а й зрозуміти механізм самого впливу, який задіяний у цьому процесі.

В статье рассматриваются вопросы, касающиеся методов проектирования средствами массовой информации социальных проблем, а именно практика установления повестки дня, прайминга и практика фрейминга. Каждая из вышеупомянутых практик проектирования социальной проблемы рассматривается в рамках современных украинских политических реалий относительно так называемой языковой проблемы. Практика воздействия на процесс сложных социальных обстоятельств дает возможность не только зафиксировать результат воздействия, но и понять механизм самого воздействия, который задействован в этом процессе.

Key words: construction of a social problem, media practices, establishment of the agenda, priming, framing.

Formulation of the problem. Solving the problems of society is an integral part of the social policy of any state. The decision to channel state resources to the settlement of a particular social problem is the scope of the political struggle of the social problematization subjects. The status of "social problem" emphasizes the need for decision-making within the framework of social policy to regulate complex social circumstances. Uncomfortable circumstances, which are referred to as a social problem, "require" to do "something" to get out of the discomfort zone into a zone of comfortable system existence. Various actors take part in the process of social problem-making. The most influential among them is the mass media; in many cases they determine our understanding of social problems. Consequently, the fact of the theme interpretation in the media by different subjects of problematization process seriously affects their success. Practices of influence as routine actions and actions of agents, that is, the media, on the process of challenging complex social circumstances, make it possible to fix not only the result of influences, but also to understand the mechanism of influence itself.

The analysis of researches and publications. Various aspects of the problems of social practice in the mass media were studied in Ukraine by M. Kornienko, O. Lavrik, T. Semigina, L. Skokova, O. Tkachenko, T. Frolova, A. Chekyshev, K. Shenderovsky and others. A journalistic view of social problems is reflected in the collection of materials under the general editorship of K. Shenderovsky [1], where 
the authors state that the media become a repeater of social problems and actually "objectify" them, while identifying the risks of this process - the complexity in assessing the "questionable" social problems and hanging labels. The greatest danger that arises when identifying social problems in media communications is that they contribute to the actualization of short-term and superficial public interest in the problem. Under the mass conditions social problems "highlighted by the media" have actually invincible interest. They are "sold" to the public under the necessary angle [1, p. 13]. In Ukraine, there are no studies that would analyze the role of the media in the process of transforming the complex social circumstances into a social problem.

The purpose of this article. Taking into account the above, the aim of the article is to analyze the activity of the mass media as a subject of the social process in order to identify the pecualiarities of the influencing practices of social problem designing in modern Ukraine on the example of the so-called "language problem".

Basic material presentation. The theoretical and methodological foundations of the research are based on the constructionist approach in the analysis of social problems. Representatives of this approach treat the problem as a product of collective definition [2, p. 53], "as the activity of individuals or groups that express dissatisfaction and act with requirements for some foreseeable conditions" [3, p. 75]. Constructionist studies often determine the interests of actors in putting forward a social problem that explains why this problem has arisen.

According to S. Hilgatner and C. Bosk, social problems argue among themselves in attempts to attract the attention of the public and politicians. These competitions take place on the so-called "public arenas", to which researchers attributed the legislative and executive branches of power, the media, various organizations, scientific communities [2, p. 62]. In "public arenas", the problems are discussed, selected, defined, interpreted and presented to the public. Each arena has its own "capacity", which limits the number of social problems that the arena can take at one and the same time. This restriction turns this competition into a critical and central one in the process of collective definition, namely, the competition between problems becomes the competition between social groups. A typical statement about the problem states that it exists, it is important, includes the definition of causal responsibility (moral, political) and offers a "recipe" to solve or resolve the problem, reducing harm from it.

Due to their features, the media represent a picture, the proportions and properties of which, in comparison with social reality, can be changed, but not infinitely. They can be compared to a magnifying glass that increases certain social problems. The impact of the media is obvious, but it is very hard to fix it. As the experience of research shows, media influence is always a result of media dominance of a single version of the interpretation, irrespective of whether it is a list of "important" problems or interpretations of a specific social problem. If there is a task to understand the role of the media in the process of constructing social problems, it is necessary to specify the practices in which this inefficient influence on the change in the logic of perception of social problems can be made. At the present moment, at least three practices of media influence on the audience have been revealed and described. All three practices are based on the notion that our knowledge of social reality is an interpretation that is formed with a significant influence of the media.

First of all, it is a practice that allows you to attract public attention to social problems. Attention of the media can force the public and politicians to realize that the problem exists and that it needs to do something about it. This form of media influence on the public is called the practice of setting the agenda.

The basic assumption of setting the agenda practice is that news is not a mere reflection of reality, but a socially constructed, edited reality. In its most general form, setting the agenda is the creation, through the media, of public awareness of key issues. At the heart of this statement there are two main theses: media do not reflect reality, but filter and shape its perception; the focus of the media on several issues and topics leads to the fact that the public perceives these issues as more important than others.

When the media appeals to certain events and problems, these issues begin to be perceived by the audience as worthy of attention. The theory of "establishing an information agenda" describes the potential of the media in influencing the perception of the importance of the themes of the social agenda. The media offer the audience an "information menu" in which "the first dish" is considered to be the one most frequently mentioned. Outside this "information menu" the "unnecessary" themes are taken away, while the "necessary" ones are often repeated, naturally gaining significance in the eyes of the audience. When in the media reports a problem is addressed, the so-called "ignition" of some problem zone (usually due to other problem areas) occurs in the consumers' minds of media content.

Consequently, the potential of media influence through the practice of establishing an agenda involves the question of whether to be or not to be a social problem and reveals itself through a few moments:

- mass media become an important source of information about the existence of a social problem;

- the media declare the existence of the problem and impose the idea that something should be done with it;

- by filtering a large number of complex social circumstances, the media focus their attention on a few of them, thus creating an image of their "importance" and "priority" in reality. 
Let us try to consider these practices of influence on the process of social problems on the example of the "language" issue in Ukraine, which, over the years of independence, has become one of the most significant in political discourse. The background for the existence of a "language problem" is the linguistic situation in Ukraine itself, which, if not to resort to numerous figures and percentages, can be characterized by the basic features that make it difficult and transform into a problem: the division of the population into at least two language groups - Russian-speaking and Ukrainian-speaking ones, which are approximately equal in quantitative composition and do not coincide with ethnic groups; territorial and socio-territorial polarization of language preferences of citizens and the formal and controversial character of the Ukrainian language legislation [4, p. 235-236].

Language choice both for Ukrainian and Russian-speaking groups is a symbol of identity, so the language issue as a factor of identity works on a subconscious level. Thoughts about the language problem, its existence or non-existence, causes, solutions of projects are quite different. These thoughts articulated through the media, constitute what might be called "the discourse of the language problem" in Ukraine.

In the semantic field of discourse of the language problem, first of all, the question is whether there exists or does not exist a "language problem" in Ukraine. The existence of language problems is invariably "supported" by the media, which are used as a tool by those politicians who benefit from raising it on the shield. The language issue during the period of electoral battles is "thrown" into political discourse through the establishment of the agenda and use of it as a means of obtaining political dividends. Experts have repeatedly stressed that this scenario would distract voters from the failure of economic reforms, from corruption and that the separation of the electorate for and against the "language" is mathematically much more advantageous to the authorities than the division of voters on the basis of the attitude towards "improvement" [5].

In particular, a new impetus for the promotion of the "language problem" was provided with the adoption of the Law "On the Basics of State Language Policy" by Verkhovna Rada in July 3, 2012, the so-called "law of Kolesnichenko - Kivalov". And in April 2019, Verkhovna Rada of Ukraine adopted the new Law "On Ensuring the Functioning of the Ukrainian Language as a State Language". The law was adopted at a fast pace. On February 28, 2019, a year passed since the Constitutional Court of Ukraine recognized the scandalous "law of Kolesnichenko - Kivalov", which significantly strengthened the position of the Russian language, as unconstitutional. From that moment a kind of linguistic-legal vacuum was formed, which was to be eliminated as soon as possible. On the eve of the election, discussions around the draft of a new law became hotter and less constructive. The bill was already called "repressive". In December 2018, the profile committee of Verkhovna Rada finalized it by considering 2059 amendments affecting almost all articles of the document, from which they tried to exclude some statements or to replace certain clauses [6].

One of the artist $\mathrm{O}$. Roitbrud (a Jew by origin who lives in Ukraine) talking about the language problem in his interview metaphorically commented on this situation: "This is a technology of playing off with two parts of Ukraine. $<\ldots>$ In order to mobilize and scare the East. $<\ldots>$ That the voters in the East, instead of voting for a more adequate social program, an adequate civilization project or other economic model, voted "for their own people", because "terrible bandera" will force them to speak Ukrainian, and whoever does not want will be shot" [7].

Positions "for" and "against" the social problem of language issues are supported not only among politicians, but also among journalists. On the one hand, a poll conducted among Kyiv political journalists from 7 to 11 August 2006 showed that almost $70 \%$ of the interviewed journalists said that the linguistic problem was fictitious, rather controversial, or purely political and it does not affect ordinary Ukrainians. However, more than $60 \%$ of respondents believed that the language problem poses a threat to Ukraine or Ukrainians. True, for political journalism, the "language theme" is a field in which one can demonstrate his/ her journalistic capabilities and earn a "name" for him/herself [8].

One of the positions regarding the existence of the "language problem" lies in the fact that it (i. e. the problem) is not recognized. There is no language problem in Ukraine at all; what's happening around the language theme is the games of careless politicians. By the way, sometimes the politicians themselves believe that the "language problem" in the Ukrainian society is thought to be foolish. In particular, the leader of the party "UDAR" V. Klychko, Kyiv mayor, in July 2012 said that Ukraine has no problems with the Russian language, and those politicians who extract "linguistic" issues on the eve of the elections are only trying to divert the attention of people from real problems and from their own political defeats [9]. If the language problem does not exist, if it appears to be a phantom, then paying attention to all that it should be stopped as well as talking about it, and then the problem itself will disappear.

Instead, there is another position, the proponents of which state that the language problem exists, and "to disregard the problem of language means to ignore the importance of the quality of the air we breathe" [10]. From the applied use of the language problem, it does not lose its importance "<... it will depend on the resolution of the very linguistic issue to a significant (very, very significant) degree, whether 
the whole worldview gap between the "two Ukraines" will smooth out, or whether it will only deepen. Will these "two Ukraines" understand each other?" [11].

Consequently, strange as it may seem, the language problem appears on the political sky of the country at a time when it allows you to score points for politicians who promise to solve it "ultimately and irrevocably". And this is supported by the practice of establishing an agenda that is used by the media.

The practice of priming transfers the emphasis from the very problem to those connotations that stand behind it. According to one of the first researchers of this kind of media practice D. Domke, the definition of priming is "a process through which labilized mental structures can influence the way people value other concepts and ideas" [12]. Priming is the effect of the previous information on the perception of a person's continued active participation, or, in other words, the activation of specific associations in memory. In general, priming can be compared with an autopilot, which at the subconscious level "adjusts" human behavior and unloads its consciousness for more important tasks. Priming accelerates the recognition of incentives that are identical to the primary information or come together with it in one semantic category. So, highlighting some of the problems and ignoring others, the media can change the standards with the help of which people value the work of government structures. The essence of priming as a cognitive phenomenon is that verbal and nonverbal stimuli trigger certain considerations that an individual uses to assess a controversial issue.

Since priming can affect the decision of the problem both positively and negatively, despite the intentions of the individual, this phenomenon is attributed by scientists to the class of spontaneous and invisible influence on solving problems. The predominance of the mass media during the election campaign of defense-related news, encourages citizens to evaluate candidates for their activities, first of all, in this problem area, which becomes the context for judging candidates [13].

Thus, priming as a media practice of challenging complex social circumstances complements the previous practice of setting the agenda and solves the question of whether a social problem will exist or not in such a way that by its being to silence the existence of all other problems, namely:

- activates certain schemes for assessing the controversial issue;

- raises the media rank of a specific social problem;

- sets the standard for assessing the situation around complex social circumstances, in particular, the actions or inactions of politicians;

- transforms a concrete social problem into a criterion for measuring the effectiveness of the political actors' functioning.

This is how the situation around the language problem develops. In the mass consciousness there is no recognition of the prevailing importance of the "language problem", but it is imposed on public discussion, in order to turn it into a sort of criterion for the effectiveness of the activities of various political actors. Public policy behaves in a way that confirms its existence, trying to solve legislatively the problems that seemingly do not exist. Experts point out that: "<... the political purpose of the law (it refers to the Law "On the basics of the state language policy") is to introduce hysterical notes in the election situation $<\ldots>$ to focus people's attention on those issues (humanitarian, not economic and social), which should be considered in the second, and not in the first place" (M. Popovich, Institute of Philosophy) [14].

Another form of media intervention in the process of social issues is framing. The basis of framing is related to the peculiarities of the cognitive process. D. Scheufele believes that framing, unlike agenda setting and priming, does not increase the visibility of the problem, but rather "causes explanatory schemes that affect the interpretation of incoming information" [15].

Framing suggests that journalists and other communicators provide information that appeal to hidden (implicit) schemes that exist in human consciousness. First of all, frames are tools that help simplify the presentation of complex social problems and make them accessible to the majority. Later, the frame begins to be interpreted not only as a simplification tool, but also as a schema of interpretation.

A frame is a kind of cognitive scheme that allows social subjects to match the actual situation with the social template, identify it, categorize, understand, select and make an adequate decision. The frames arise on the basis of existing cultural codes, are assimilated in the course of socialization, develop together with the accumulation of personal experience and provide mutual understanding among members of social groups. At the symbolic level they help to intelligently structure the social world and embed new information in the existing picture of the environment.

In preparing a message, a journalist (or any other actor) forms a "story frame" as a skeleton form of a typical narrative, an explanation or proof with typical actors, a plot and a logic of event development, or as a history template containing answers to meaningful questions addressed to the recipient in relation to the situation described. This is called a media frame. It is the media frame that allows journalists to quickly "pack" the problem into a template that already exists and broadcast it to the public.

If a frame is a schema, a social problem scenario, framing is the use of cognitive schemes to detect, understand, identify, and categorize events or information. Framing is already a practice of purposeful 
activation of cognitive schemes by the actor for the situation or message interpretation management by the addressee, or the previous creation of the "lawyer's frame" by the actor of the controversial issue or problem [16].

An American sociologist R. Entman in 1993 [17] made an attempt to combine all that was done regarding the theory of frames into a single concept and to suggest that the essence of the framing be this: "to choose certain aspects of reality and to make them more visible in the text of the message, promoting such a definite vision of the problem, interpretation of its causes, moral judgment and possible solution". Accordingly, in order to understand the effectiveness of the frame, it is necessary, in his opinion, to clarify the concepts of "visuality/noticeability", "formatting" and "importance" (salience, sizing and importance).

The main elements of the framing practice via the media are two points:

- narrowing of the problem field, which contributes to the greater probability that the public agenda will reflect the agenda of political elites;

- promotion of correct interpretations of social problems. This is the strategic goal of any actor - to create mental images beneficial for themselves and make up evaluation matrices of specific social reality fragments in the images of the world target groups. In political discourse, framing the media agenda forms a central strategy for managing news as a system of communicative technologies used by political actors not so much for public information of citizens, but for managing public opinion in their own interests.

Using the frame of complex social circumstances leads ultimately to assigning them a problem status or resonance because of placing it in the category of value-loaded topics and narrative formulas that are remembered by the public. The frames reflect the constructs of "moral competence" that exist at the common sense level: their use usually assumes that the audience is obligated to recognize the importance of the expressed values and, accordingly, the use of this frame by those who make claims-requests. The frames are intended, as a rule, to create an emotional background for the perception of the problem and use terms and narratives from the "moral competence" category of the political discourse target audience for this purpose. Framing of social problem is a process of conscious use of a defined problem frame which can be represented as components of rhetorical argumentation: the grounds, which confirm the obvious existence of the problem; conclusions that provide an understanding of what is needed to solve the problem of action and justification, that is, considerations and values that the public must share, in order to link the grounds and conclusions into a single logical chain of the statement-requirement for the problem. Thus, framing provides reasoning that combines the basis of a problem or facts with conclusions required to resolve the problem.

Schemes of the framing of problematic versions of the language issue in Ukraine depend on the position of the political group, which proposes to settle it and declares it in the media. In general, at least two political and ideological groups (names and descriptions are proposed in the Internet publication of $O$. Myshlovskaya) take part in the so-called linguistic debate in Ukrainian society. In the last presidential election, these two groups were embodied in the positions of two candidates in the second round: P. Poroshenko vs. V. Zelensky. O. Myshlovskaya calls the first group national statesmen. The creed of this group - "Language is the soul of the people and the main feature of the state", that is, the language is identical to the state, and consequently, the survival of the Ukrainian state depends on the "real" introduction of the Ukrainian language into all spheres of state and public life. Accordingly, linguistic homogenization of society is considered a factor of consolidation of the state and nation. The author notes that this position has become a kind of "official ideology" of post-Soviet Ukrainian science and education, some public organizations [18]. The flowering of the Ukrainian language after centuries of total russification is a mission that we must accomplish, - said the current president P. Poroshenko [19].

The second group is the supporters of the linguistic status quo, who, according to the author of the publication, do not share the fundamental ideas of Ukrainian statehood and perceive the first group as a threat to themselves. The status quo for the most part is understood by them not only as the actual domination of the language, but also as the consolidation of this domination by giving it a certain legal status - state or at least official one.

The presence of these two components in the language discourse of the country is confirmed by the content of the political and ideological arguments, the framing of the "linguistic issue" in the direction of problematization and deproblematization, which is most often heard in the polemic of the linguistic issue in Ukraine. The argument touches on such topics as the relationship of language and statehood, the democratic and legal foundations of the solution of the language problem, the restoration of historical justice in the language sphere, the future fate of the Ukrainian and Russian languages. The supporters of the national-state position (the Ukrainian version of the problem - for Ukrainization) and the position of the so-called linguistic status quo, above all, actualize the frame of "catastrophic circumstances" - the most rigorous of all possible technological framing techniques to draw attention to the identified complex social circumstances with the state of the Ukrainian or Russian language in the state. The "catastrophic circumstances" rhetoric is used to create the image of a catastrophe for complex social circumstances. 
This rhetoric is most often used in a situation of so-called "moral panic". Rhetoric of "disaster" requires immediate action, if it is not committed, it can lead to other problems. Problem applicants who use a similar frame can recognize other problems, but use this frame to show that all other problems are tied to a certain one, that it is possible to create a coalition and thereby attract more supporters of this formulation of the problem. In the "catastrophic circumstances" frame of the national-state direction representatives, one can follow the following logic: the inadequate functioning of the language of the titular ethnic group entails inferior functioning of the culture, which, in turn, results in inadequate functioning of the state, which in turn leads to catastrophic consequences for the state. The state of actual existence of the Ukrainian language is subjected to catastrophizing; even the expression "death of the Ukrainian language" is sometimes used. Using such emotionally loaded expressions raises the status of complex social circumstances and brings them into the orbit of "problem".

Framing according to the "catastrophic circumstances" scheme of the status quo position supporters is just as categorical. They critically evaluate the policy of Ukrainianization of society, they believe that the policy of Ukrainization leads to the degradation of society. The adoption of a new law on language is assessed by the newly elected President V. Zelensky as not conducive to the consolidation of Ukrainian society. The methods, which are supposed to implement this law - prohibition and punishment, complication of bureaucratic procedures, can become an obstacle to the implementation of a strategic goal - the development of the Ukrainian language, dissemination of its use [20].

The reaction to the forced Ukrainization of the Russian-speaking population is the calls for civilized bilingualism in the state. And in order to ensure the domination of the language of the country, it is necessary to ensure the domination of their own culture. For Ukraine, the recipe is simple: we will take care of the development of Ukrainian culture, gradually injecting it into a growing generation and gaining a strong Ukrainian language. This process is long and natural [21].

The analysis made allows us to draw the following conclusions. The construction of a social problem occurs with the active participation of the media. At least three practices in the design of social problems are used by media representatives: the practice of setting the agenda, the practice of priming and practice of framing. According to the logic of the agenda setting and priming, there is an increase in media ranks of controversial issues along with their attributes due to the animation of such messages to the public, which cover "correct questions" with "correct attributes" and implicitly present the "correct criteria" for their assessment. The media practice of framing sets the "correct interpretation" in illuminating the social problem, formatting the social problem in a perspective in which one or another political force can and is going to resolve it.

The political story of the "language problem" in Ukraine is far from being complete. It has long passed the stage of birth, and there are groups (including political ones) who interpret it as a social problem; it is periodically "released" to public arenas through the media and then exposed to political pressures on both sides; judging by the fact that the law "On the Principles of State Language Policy" was adopted, this social problem has even passed the stage of institutionalization, but the removal or at least fragmentation of the problem did not occur. The new law "On Ensuring the Functioning of the Ukrainian Language as a State Language" is an attempt once again to resolve the problem of language in Ukraine, on evidence of a new stage of the problem development.

\section{References:}

1. Медіакомунікації та соціальні проблеми : збірка навчально-методичних матеріалів і наукових статей : у 3 ч. / К. Шендеровський та ін. Київ : Ін-т журналістики КНУ, 2012. Ч. 1. 288 с.

2. Hilgatner S., Bosk C. The rise and fall of social problems: a public arenas model. American Journal of Sociology. 1988. Vol. 94. № 1. P. 53-78.

3. Spector M., Kitsuse J. Constructing Social Problems. New York : Aldine De Gruyter, 1987. 400 p.

4. Заремба О., Римаренко С. Механізми політичної мобілізації мовних груп: антрепренери, гасла, заходи. Мовна ситуація в Україні: між конфрліктом і консенсусом. Київ : ІПіЕНД ім. І.Ф. Кураса НАН України, 2008. С. 235-257.

5. Мельник М. Закон про мову: засади мовної політики чи засідка? Дзеркало тижня. 2012. № 25. URL: https://dt.ua/LAW/zakon_pro_movu_zasadi_movnoyi_politiki_chi_zasidka.html (дата звернення: 27.04.2019).

6. Закон про державну мову: хто та де муситиме говорити українською. URL: https://24tv.ua/rada_pidtrimala_zakonoproekt_pro_movu_hto_i_de_musitime_govoriti_ukrayinskoyu_ n1042268 (дата звернення: 27.04.2019).

7. Климончук О. Едіпів комплекс щодо Шевченка гальмує розвиток української культури. - Ройтбурт. URL: http://gazeta.ua/articles/opinions-journal/442548 (дата звернення: 27.04.2019). 
8. Левченко О. Соціологічні дослідження щодо проблеми мови в Україні. Мовна ситуація в Україні: думка молоді. Київ : Молодіжна альтернатива, 2007. С. 13-16.

9. Кличко В. «Мовне» питання - це спроба влади відволікти українців від власних поразок. URL: http://2k9.cmsys.it/news/?id=17518 (дата звернення: 27.04.2019).

10. Ференц В. Два шляхи до мовного закону. Українська правда. 2008. 21 березня. URL: http://www.pravda.com.ua/articles/2008/03/21/3398934/ (дата звернення: 27.04.2019).

11. Бахтєєв Б. Битва за симулякри. Українська правда. 2006. 5 червня. URL: http://www.pravda.com.ua/articles/2006/06/5/3113706/ (дата звернення: 27.04.2019).

12. Domke D., Shah D., Wackman D. Media priming effects: accessibility, association, and activation. International Journal of Public Opinion Research. 1998. № 10. P. 51-75.

13. Chong D., Druckman J. A theory of framing and opinion formation in competitive elite enviroments. Journal of Communication. 2007. Vol. 57. P. 99-118.

14. Соломко И. Рационально об эмоциональном. Директор Института философиии - о будущем украинского языка. Кореспондент. 2012. 6 липня. URL: https://korrespondent.net/ukraine/politics/ 1368693-korrespondent-racionalno-ob-emocionalnom-direktor-instituta-filosofii-o-budushchemukrainskogo-yaz (дата звернення: 27.04.2019).

15. Scheufele D. Agenda-setting, priming, and framing revisited: another look at cognitive effects of political communication. Mass Communication and Society. 2000. № 3. P. 297-316.

16. Tewksbury D., Jones J., Peske M., Raymond A., Vig W. The interaction of news and advocate frames: manipulating audience perceptions of a local public policy issue. Journalism and Mass Communication Quarterly. 2000. Vol. 77. P. 804-829.

17. Entman R. Framing: toward clarification of a fractured paradigm. Journal of Communication. 1993. Vol. 43. № 4. P. 51-58.

18. Мишловська О. Парадокси мовної політики. Українська правда. 2007. 12 липня. URL: http://www.pravda.com.ua/archive_day/20070712.htm (дата звернення: 27.04.2019).

19. Порошенко заявив, що схвалить закон про українську мову, щойно він надійде на підпис. URL: https://gordonua.com/ukr/news/politics/-poroshenko-zajaviv-shcho-shvalit-zakon-pro-ukrajinskumovu-jak-tilki-vin-nadijde-na-pidpis-914929.html (дата звернення: 25.04.2019).

20. Порошенко та Зеленський висловилися щодо закону про мову. URL: https://vybory.detector. media/2019/04/25/poroshenko-ta-zelenskyj-vyslovylysya-schodo-zakonu-pro-movu/ (дата звернення: 27.04.2019).

21. Бережна I. Мовна політика, чи мова політики. «Lapsus linguae» (Не робіть помилок щодо мови). Українська правда. 2008. 22 лютого. URL: http://www.pravda.com.ua/articles/2008/02/22/3380250/ (дата звернення: 27.04.2019). 